\title{
Validation of educational booklet: an educational technology in dengue prevention
}

\author{
Validação de cartilha educativa: uma tecnologia educacional na prevenção da dengue \\ Validación de cartilla educativa: una tecnología educacional en la prevención del dengue
}

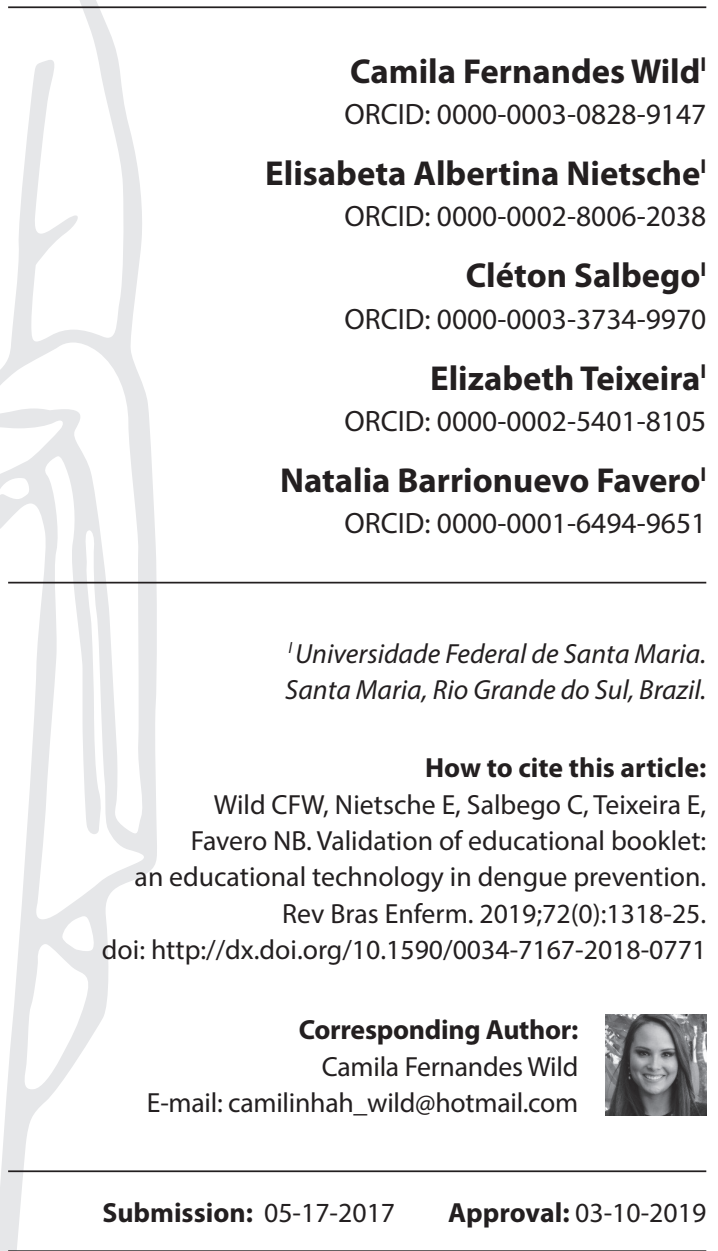

\begin{abstract}
Objective: to validate a booklet on dengue prevention in order to make it an educational technology to be used with the population. Method: methodological study, carried out with two groups of judges specialized in health and other areas. For data analysis, the calculation of Content Validity Index was carried out. Results: the booklet, in general, was considered valid by the expert judges, since it obtained an overall CVI of $70 \%$. However, it has undergone a textual and aesthetic re-elaboration. The changes were based on the substitution of expressions, phrases, information additions and language adequacy. The illustrations were redone, adding clarity, expressiveness, movement, interaction and contextualization. Conclusion: the booklet is valid to be used for the population, with the purpose of informing, in a playful way, the forms of prevention and combat to mosquito transmitting dengue.

Descriptors: Validation Studies; Educational Technology; Dengue; Health Education; Nursing.
\end{abstract}

\section{RESUMO}

Objetivo: validar uma cartilha sobre prevenção da dengue, a fim de torná-la uma tecnologia educacional para ser utilizada com a população. Método: estudo metodológico, realizado com dois grupos de juízes especialistas da Saúde e de outras áreas. Para a análise dos dados, foi realizado o cálculo de Índice de Validade de Conteúdo. Resultados: a cartilha, em geral, foi considerada válida pelos juízes especialistas, visto que obteve um IVC global de $70 \%$. Entretanto, passou por uma reelaboração textual e estética. As alterações recaíram sobre a substituição de expressões, frases, acréscimo de informações e adequação de linguagem. As ilustrações foram refeitas, acrescentando clareza, expressividade, movimento, interação e contextualização. Conclusão: a cartilha é válida a ser utilizada para a população, com o objetivo de informar, de maneira lúdica, as formas de prevenção e combate ao mosquito transmissor da dengue.

Descritores: Estudos de Validação; Tecnologia Educacional; Dengue; Educação em Saúde; Enfermagem.

\section{RESUMEN}

Objetivo: validar una cartilla sobre prevención del dengue, con el fin de hacerla una tecnología educativa para ser utilizada con la población. Método: estudio metodológico, realizado con dos grupos de jueces especialistas de la Salud y de otras áreas. Para el análisis de los datos, se realizó el cálculo del Índice de Validez de Contenido. Resultados: se considera que la cartilla, en general, fue considerada válida por los jueces especialistas, ya que obtuvo un IVC global del 70\%. Sin embargo, pasó por una reelaboración textual y estética. Los cambios recae sobre la sustitución de expresiones, frases, acrecimiento de informaciones y adecuación de lenguaje. Las ilustraciones fueron rehechas, añadiendo claridad, expresividad, movimiento, interacción y contextualización. Conclusión: la cartilla es válida para ser utilizada para la población, con el objetivo de informar, de manera lúdica, las formas de prevención y combate al mosquito transmisor del dengue.

Descriptores: Estudios de Validación; Tecnología Educativa; Dengue; Educación en Salud; Enfermería. 


\section{INTRODUCTION}

Dengue is transmitted by the Aedes aegypti mosquito and is considered a major public health problem in the world and it is a rapidly spreading viral disease ${ }^{(1)}$. In 2015, 1,688,688 cases of the disease were reported in Brazil, the highest number recorded in the historical series, started in $1990^{(2)}$. In 2016, there were 1,500,535 probable cases of dengue in the country ${ }^{(2)}$.

Even with the decrease of cases, in the first three months of 2017 , compared to the previous year ${ }^{(2)}$, the fight against the mosquito transmitting dengue must be constant. The best way to prevent the disease is still the fight against the mosquito vector, preventing it from proliferating. Besides dengue, the Zika and Chikungunya viruses are diseases that circulate in Brazil and are transmitted by the same vector.

Therefore, the participation of the population in this process is extremely relevant. Through health education actions, carried out by health professionals, these can become collaborators for the mosquito elimination.

In this sense, the teaching process should be the foundation for building and sustaining professional training in health, adding values, knowledge, and experiences since it is understood by educational actions the teaching-learning practices developed with the aim of discussing and promoting knowledge. Thus, it would subsidized the decision-making, having as reference the critical reflection of the ethical and legal aspects of the profession ${ }^{(3)}$.

Health professionals, especially nurses, can use a variety of technologies to creatively carry out the process of caring and educating, in this context, the most important are Educational Technologies (ET). These technologies should be used, in order to favor the participation of the subjects in the educational process, contribute to citizenship and the development of the autonomy of those involved ${ }^{(4)}$.

The ET is considered "a body of knowledge enriched by man's action, and it is not just the construction and use of artifacts or equipment"(5). ETs are also important devices for the measurement of teaching and learning processes between educators and learners in various processes of formal-academic and formalcontinuing education ${ }^{(6-7)}$.

It should be noted that the materials/tools, products and/or processes used for the development of educational actions can be considered ET as they are submitted to a systematized process of construction and validation ${ }^{(6-7)}$.

The study is justified by the high numbers of dengue cases recorded in Brazil over the years and the need to use technological tools as a strategy for education and prevention of individual and collective health for dengue control. The materials and didactic content found and made available on the Internet were difficult to access, extensive and didactic.

Thus, for the development of this study, it was questioned: is a booklet, developed for dengue prevention, a valid tool to be used as ET, according to expert judges?

\section{OBJECTIVE}

To validate a booklet on dengue prevention in order to make it an ET to be used with the population.

\section{METHOD}

\section{Ethical aspects}

The development of this research complied with national and international standards of Research Ethics Involving Human Beings.

The study was approved by the Research Ethics Committee of the Universidade Federal de Santa Maria. The judges participating in the study signed the Free and Informed Consent Form (FICF), confirming their consent to participate in the study. The ethical precepts of human research were respected.

\section{Design, sample and period of study}

This is a methodological development study to validate a booklet on dengue prevention. The study sample consisted of two distinct groups of expert judges. The first group was called "Health Judges", necessary in the validation process because of the importance of judging the specific content and thematic of the booklet. The second group, "judges from other areas", considered important for the judgment of appearance, with regard to graphics, diagramming, visual communication, information layouts and expressive language of the material. The survey of the judges and the data collection were carried out from March to June of 2016.

For the selection of judges in the health area, four inclusion criteria were established: experience with the theme of the study; stricto sensu graduate degree and scientific production related to health education; and have scientific production related to the development of technologies. For judges from other areas, the following criteria were established: having at least two years of experience in the area of activity; have, at least, lato sensu graduate degree; scientific production and teaching experience.

It should be emphasized that the inclusion criteria were adapted from another validation study ${ }^{(8)}$. Only judges whose profiles fulfilled at least two inclusion criteria were included. They fell under both types of judges. As exclusion criteria, the judges who requested aid of cost were established; who remained for more than 30 days without returning the tools of the study or without communication with the researchers, after attempts of contact.

For the selection of these judges, a curriculum survey was carried out in the Lattes Platform, using the "search by subject" tool, with the keywords "dengue", "educational technology" and "health education" for health professionals; "education", "visual arts", "communication" and "designer" for judges from other areas, who were also selected through nominations from other professionals.

Judges were invited to participate in the research, by means of an invitation letter sent by e-mail (personal or institutional), or by the "contact" section of the Plataforma Lattes (Lattes Platform). To the judges who accepted, they were asked for their postal address, for sending the validation tool, a sealed envelope for the return of the material and two copies of the FICF and a printed version of the booklet.

Participants were offered a maximum period of 30 days for the return, from the delivery of the material.

130 judges were invited. 82 accepted to participate in the research and sent their postal addresses for the referral of materials. 
However, after sending the material, confirmation of receipt at the addresses indicated and the time stipulated for the return, the tools returned 56 judges ( 29 from the health area and 27 from other areas) who composed the study sample.

\section{Collection and analysis of results}

Expert judges had the function of judging the booklet on the content, through the following indicators: objectives-purposes, goals or ends (which one wishes to achieve with the use of the booklet); structure and presentation of the guidelines; writing style; relevance (characteristics of the degree of significance of the presented material). A space for suggestions has been made available.

The questions of the tool were divided into blocks. Respondents, considering the scores for trial, opted for the following answers: (1) Great; (2) Very Good; (3) Good; (4) Average. If the answer was "good" or "average", the judges would have to enter a descriptive argumentative opinion to justify the answer.

For the quantitative analysis of the data, the Content Validity Index (CVI) was calculated. CVI measures the proportion of judges who agree on a particular aspect of the tool and its items ${ }^{(9)}$. This method employs the use of a Likert scale, with a score of one to four. The score index is calculated by means of the sum of agreement of the items that were marked with option "1" and "2" divided by the total number of answers ${ }^{(10)}$. Regarding the averages obtained, the items should reach CVI greater or equal to $0.70(70 \%)$, adopted as a decision criterion on the pertinence and the acceptance of each item. The items that obtained less than expected averages were modified, taking into account the judges' comments and suggestions.

To evaluate the booklet as a whole, the overall CVI calculation was performed, which consisted of the sum of all CVI calculated separately and divided by the number of items of the tool ${ }^{(11)}$. Data were compiled and analyzed using the Statistical Package for Social Sciences (SPSS), version 17.0. These data were treated based on the descriptive statistical analysis, with simple frequency distribution.

\section{RESULTS}

The results presented in Table 1 correspond to the profile of the 29 expert judges in the health area, according to gender, age, education and city/state.

As to the profile of judges in the Health area, $89.7 \%$ (26) were female, age ranged from 29 to 77 years and $82.8 \%$ (24) of the judges were over 40 years of age. Regarding education, the seven categories of professionals stood out. Nurses appeared in greater numbers and had extensive experience in the development and validation of ET, and health education Nurses appeared in greater numbers and had extensive experience in the development and validation of ET, and health education. It was also highlighted the number of doctors, with predominance in the areas of infectology, virology and public health, respectively. The judges covered four regions of Brazil, with predominance of the Southeast region, $54.9 \%$ (16).

In Table 2, the results presented refer to the profile of 27 expert judges from other areas of interest, according to gender, age, education and city/state.
Table 1 - Characterization of expert judges in the health area, Santa Maria, Rio Grande do Sul State, Brazil, 2017

\begin{tabular}{|c|c|c|}
\hline Variables & $\mathbf{n}$ & $\%$ \\
\hline \multicolumn{3}{|l|}{ Gender } \\
\hline Female & 26 & 89.7 \\
\hline Male & 3 & 10.6 \\
\hline \multicolumn{3}{|l|}{ Age } \\
\hline 29 to 39 years & 8 & 27.6 \\
\hline 40 to 59 years & 16 & 55.2 \\
\hline$\geq 60$ years & 5 & 17.2 \\
\hline \multicolumn{3}{|l|}{ Education } \\
\hline Nursing & 11 & 37.9 \\
\hline Medicine & 8 & 27.6 \\
\hline Biological Sciences & 5 & 17.2 \\
\hline Pharmacy & 2 & 6.9 \\
\hline Physiotherapy & 1 & 3.4 \\
\hline Psicology & 1 & 3.4 \\
\hline Odontology & 1 & 3.4 \\
\hline \multicolumn{3}{|l|}{ City/state } \\
\hline São Paulo-SP & 6 & 20.7 \\
\hline Rio de Janeiro-RJ & 5 & 17.2 \\
\hline Santa Maria-RS & 3 & 10.3 \\
\hline Florianópolis-SC & 2 & 6.9 \\
\hline Recife-PE & 2 & 6.9 \\
\hline Salvador-BH & 2 & 6.9 \\
\hline Limeira-SP & 1 & 3.4 \\
\hline Campinas-SP & 1 & 3.4 \\
\hline Curitiba-PR & 1 & 3.4 \\
\hline Toledo-PR & 1 & 3.4 \\
\hline Petrolina-SP & 1 & 3.4 \\
\hline Belo Horizonte-MG & 1 & 3.4 \\
\hline Uberaba-MG & 1 & 3.4 \\
\hline Goiás-GO & 1 & 3.4 \\
\hline São Luís-MA & 1 & 3.4 \\
\hline Total & 29 & 100 \\
\hline
\end{tabular}

Regarding the profile of the judges from other areas, $63 \%$ (17) were female, ranging in age from 26 to 74 years. Regarding education, judges with a degree in Visual Arts, Design, Industrial Design and Graphic Arts, who contributed to the improvement of the visual structure that illustrates the text of the booklet, as well as the social communication and education professionals and who assisted in the material language enhancement, stood out. There were five states and the Federal District, with predominance of the South region, with $51.8 \%$ (14). Considering the two groups of experts, the study covered judges from all regions of the country, contemplating different realities and social contexts.

In Table 3, the results presented correspond to the order of the validation tool, with the answers obtained in each item per block, according to the frequency of the variables. In other words, the number of times each valuation appeared and the result of the CVI per item.

The first block, with five items, obtained a total of 271 answers. $72 \%$ (196) answers were classified as (1) great or (2) very good; $28 \%$ (75) such as (3) good or (4) average. Of the five items in the first block (objectives), four were considered valid (1.1, 1.2, 1.3, 1.5), reaching a CVI equal to or greater than 0.70 . 
Table 2 - Characterization of expert judges from other areas, Santa Maria, Rio Grande do Sul, Brazil, 2017

\begin{tabular}{lcc}
\hline Variables & $\mathbf{n}$ & $\%$ \\
\hline Gender & & \\
$\quad$ Female & 17 & 63 \\
Male & 10 & 37 \\
Age & & \\
26 to 40 years & 7 & 25.9 \\
41 to 59 years & 16 & 59.3 \\
Z60 years & 4 & 14.8 \\
Education & & \\
Visual Arts & & \\
Social Communication & 7 & 25.9 \\
Design & 6 & 22.2 \\
Education/Pedagogy & 4 & 14.8 \\
Industrial Draw & 4 & 14.8 \\
Graphics & 2 & 7.4 \\
Sociology & 2 & 7.4 \\
Journalism & 1 & 3.7 \\
City/state & 1 & 3.7 \\
Porto Alegre-RS & & \\
Rio de Janeiro-RJ & & \\
Santa Maria-RS & 8 & 29.6 \\
São Paulo-SP & 5 & 18.5 \\
Niterói-RJ & 4 & 14.8 \\
Estância Velha-RS & 2 & 7.4 \\
Belém-PA & 2 & 7.4 \\
Pelotas-RS & 1 & 3.7 \\
Piraju -SP & 1 & 3.7 \\
Brasília-DF & 1 & 3.7 \\
Petrópolis-RJ & 1 & 3.7 \\
Total & 1 & 3.7 \\
& 1 & 3.7 \\
& 27 & 100 \\
\hline
\end{tabular}

Related to item 1.1 (information/contents are or are consistent with the daily needs of the population) and 1.2 (information/contents are important to understand what dengue prevention is), the judges suggested to include the other diseases transmitted by the vector Aedes aegypti since the preventive measures are the same. Therefore, any intervention that reduces the density of this mosquito species in the environment can consequently reduce the number of cases of the diseases, taking into account the current concern with severe cases of infection with the Zika and Chikungunya virus.

Suggestions related to item 1.3 (invites and / or instigates changes in behavior and attitude of the population: adults, adolescents and children) were also complied with. According to the judges, there was a need for a more professional approach to drawing and improving the color quality of the booklet.

From the items of the first block, it was verified that item 1.4 (may circulate in the scientific area) resulted in a CVI of 0.67 , being therefore lower than the established limit.

The judges considered the booklet as an information vehicle to be used with the population, with simple and informal language, without the use of technical language, which would require further deepening to be used in academia.

The second block of the tool, referring to structure and presentation, contained 15 items that totaled 837 answers. Among these answers, 68\% (570) were considered (1) great or (2) very good and 32\% (267) (3) good or (4) average. Among the 15 items, six did not reach the established index. The items of this block were the ones that presented greater disagreement among the judges, involving aspects such as: layout, graphics, design and language suitable for the target audience. As a result, these aspects were the most affected by changes.

Table 3 - Expert judges' answers to validation criteria

Objectives

1.1 The information/content is or is consistent with the daily needs of the population.

1.2 The information / contents are important to understand what dengue prevention is.

1.3 Invites and / or instigates changes in behavior and attitude of the population (adults, adolescents and children).

1.4 It can circulate in the scientific community of the area.

1.5 Meets the objectives of the Ministry of Health on dengue prevention.

Structure and presentation

2.1 The booklet is suitable for adults.

2.2 The booklet is appropriate for adolescents.

2.3 The booklet is appropriate for children.

2.4 The information presented is scientifically correct.

2.5 The messages are presented clearly and objectively.

2.6 The material is appropriate to the sociocultural level of the population.

2.7 There is a logical sequence of proposed content.

2.8 The information is well structured in agreement and spelling.

2.9 The style of writing corresponds to the level of knowledge of the population.

2.10 The information on the cover is consistent.

2.11 The size of the title and topics is adequate.

2.12 The illustrations are expressive and sufficient.

$\begin{array}{lllll}18 & 19 & 10 & 04 & 0.72\end{array}$

2.13 The material (paper / print) is appropriate.

2.14 The number of pages is adequate.

2.15 The exercises proposed in the booklet are objective and clear.

$\begin{array}{lllll}07 & 12 & 21 & 16 & 0.33\end{array}$

$\begin{array}{lllll}09 & 12 & 17 & 18 & 0.37\end{array}$

$\begin{array}{lllll}25 & 18 & 09 & 04 & 0.76\end{array}$

$\begin{array}{lllll}23 & 18 & 09 & 05 & 0.74\end{array}$

$\begin{array}{llllll}15 & 18 & 16 & 07 & 0.58\end{array}$

$\begin{array}{lllll}21 & 19 & 10 & 06 & 0.71\end{array}$

$\begin{array}{lllll}20 & 16 & 15 & 05 & 0.64\end{array}$

$\begin{array}{lllll}22 & 19 & 11 & 04 & 0.73\end{array}$

$\begin{array}{lllll}18 & 18 & 14 & 05 & 0.65\end{array}$

$\begin{array}{lllll}25 & 17 & 10 & 04 & 0.75\end{array}$

$\begin{array}{lllll}22 & 23 & 06 & 05 & 0.80\end{array}$

$\begin{array}{lllll}08 & 20 & 18 & 10 & 0.50\end{array}$

$\begin{array}{lllll}22 & 24 & 05 & 04 & 0.83\end{array}$

$292403-0.94$

$\begin{array}{lllll}21 & 25 & 07 & 03 & 0.82\end{array}$

To be continued 
Relevance

3.1 The themes portray key aspects that should be reinforced.

3.2 The material allows the transfer and generalization of learning to different contexts (urban area and rural area).

3.3 The booklet proposes the construction of knowledge.

3.4 The material addresses the issues that people need to know about dengue prevention.

3.5 The booklet is suitable for use in any subject in the population.

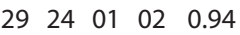

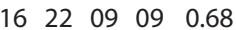

$\begin{array}{lllll}15 & 28 & 07 & 06 & 0.76\end{array}$

$\begin{array}{lllll}19 & 23 & 12 & 02 & 0.75\end{array}$

$\begin{array}{lllll}08 & 15 & 20 & 13 & 0.41\end{array}$

Note: 1. Great; 2. Very Good; 3. Good; 4. Average; *Content Validity Index.

Among items 2.1 (the booklet is appropriate for adults), 2.2 (the booklet is appropriate for adolescents) and 2.3 (the booklet is appropriate for children), which questioned the use of educational material by different audiences, only item 2.3 was judged valid by the judges.

The judges judged the booklet more directed to children, mainly, by the context, since the narrative was happening in the school environment and the majority of the personages was child.

The language used in the material was also considered childish, not creating sufficient identification to attract the attention of the adolescent and adult public in the opinion of the judges. This result can be explained by the difficulty of developing an educational material suitable for any subject of the population and for any environment.

Given the relevance of the judges' considerations, the contents and language of the book were reformulated, seeking to involve and attract, as far as possible, all segments of the population. The illustrations also contributed to judges not considering suitable material for adolescents and adults. Aspects inherent to the design of the booklet were evidenced as crucial for the achievement of the proposed objectives.

The item 2.5 (the messages are presented in a clear and objective way) obtained a CVI of 0.58 . There was a need for a restructuring of the material as a whole, with more qualified and contextualized information for the construction of a clear and objective narrative to provide the reader's involvement, for empathy and understanding of the phenomenon/problem.

Some conceptual issues have also been reviewed. One can mention, for example, the confusion between virus and mosquito, signaled by the judges. In this way, the sentences were restructured so that there was no doubt about the vector that transmits the dengue virus.

Item 2.7 (there is a logical sequence of proposed content) was also adequate according to the judges' suggestions, since it reached CVI of 0.68 . The experts suggested modifying the sequence of topics to create a narrative with rhythmic and engaging plot.

In relation to item 2.9 (the style of writing corresponds to the level of knowledge of the population), this resulted in CVI of 0.65 , a consequence of negative evaluations of other aspects of the booklet that have already been discussed as language and definition of the target audience. The material was not considered suitable for adolescents and adults, according to experts. To reach all audiences (adults, children and adolescents), different visual and verbal information is needed.

As for item 2.12 (illustrations are expressive and sufficient), it reached a CVI of 0.50 , therefore, insufficient to be validated. The graphic design of the booklet was criticized by the judges, because the visual narrative was uninviting because it was unattractive.

According to the judges, the illustrations should be contextualized with reality to dialogue with the reader. In this way, the design of the Aedes aegypti mosquito was modified, using characteristics and characters that covered the ethnic multiplicity and promoted the social inclusion.

The judges looked at the technical and graphic-specific issues, mainly about standardization in comic book development, and the use of more expressive language resources. In front of the exposed, all the visual planning of the material was remade, so that the message was not harmed.

The third and last block, contained five items of evaluation and made 280 answers. 71\% (199) were rated as "great" and "very good", and 29\% (81) as "good" and "average", and all the judges pointed out the five items in this block.

Items 3.2 (the material allows the transfer and generalization of learning to different contexts: urban area and rural area) and 3.5 (the booklet is suitable for use in any subject of the population) were not validated by the judges, since they reached CVI of 0.68 and 041 . The items reinforced questions regarding the generalization of the material for different contexts and different audiences.

Regarding the evaluation of the relevance of the booklet, according to the justification of the judges for not validating item 3.3 that discussed the transfer and generalization of learning in different contexts (urban area and rural area), there was no difference in the context and setting of the material that identified the urban and rural area. For the experts, the narrative and the images reproduced only the urban environment.

The overall CVI of the booklet was 0.70 , reaching the minimum limit established to be validated. The results confirmed the need to reprocess the material in terms of playful and informative, textual and aesthetic, especially taking into account the scientific and pedagogical argumentative quality required to encourage the population to prevent dengue.

In front of the exposed, the final version of the booklet consisted of 23 pages, plus the cover. The booklet was composed of illustrations redesigned from the judges' recommendations. Initially, the illustrations were outlined by freehand and finalized by means of digital painting in the Adobe Photoshop program. For diagramation, Adobe indesign tools were used. The texts of the comic were written, using the typography, "DK The Cats Whiskers", size 10.

Figure 1 presents the cover and some contents covered in the final version of the booklet. 

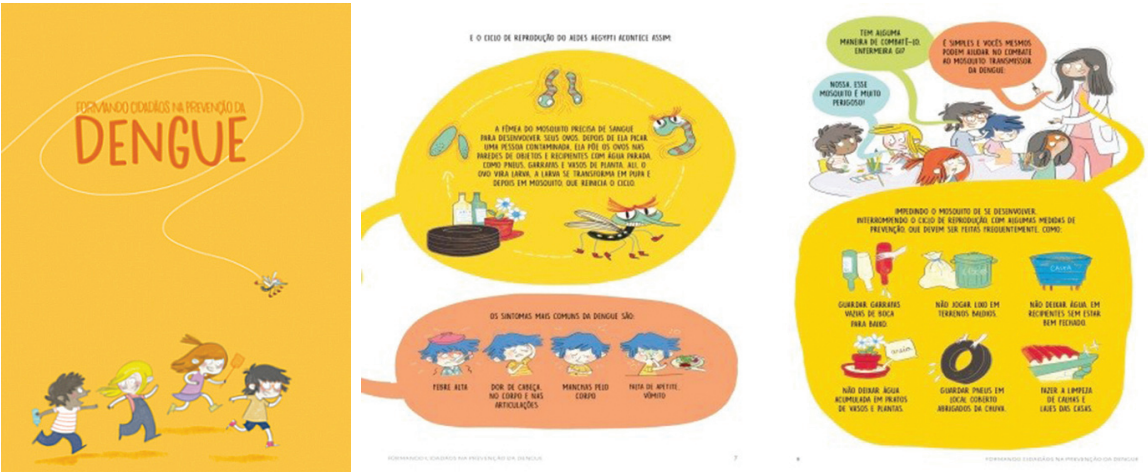

Figure 1 - Cover illustrations and contents of the booklet: educating citizens on dengue prevention adults), proving or not, its effectiveness with all segments of the population.

The health professional, in his daily life, experiences situations in which his actions are directed towards the education in the scope of health, especially the professional nurse. Given the nature of its function, as a knowledge agent, it can seek options that support it to intervene with the population, with a view to promoting well-being, social inclusion, and citizenship ${ }^{(18)}$. Thus, community participation, consciously and actively, in the surveillance and monitoring actions of Aedes aegypti has been recommended as one of the main axes of an effective control program. At the same time, it is one of the most complex tasks to be implemented.

Based on these assumptions, educational campaigns that consider the school space in dengue vector control actions are essential, aiming at the dissemination, not only of information, but also the encouragement of an active position of the citizen in the elimination of mosquito breeding sites ${ }^{(19)}$.

To do so, one must consider the quantity and type of information that the target public wants or needs to feel informed and encouraged to change attitudes. It should be remembered that decision-making also depends on previous experiences, values, beliefs and information obtained from other sources ${ }^{(20)}$.

A material written in easily understandable language, benefits user perception and satisfaction, broadens the development of their attitudes and skills, facilitates autonomy and prevention and treatment behaviors compliance ${ }^{(21)}$. This is in line with the judges' considerations regarding the information expressed in the booklet that oscillated between ambiguous, popular and scientific language.

Thus, the different forms of writing that constituted the material could make it difficult for the reader to recognize the message that the speaker sought to convey. Furthermore, a popular language was adopted in the contents of the booklet, as well as the introduction of technical terms to an appropriate extent and clarified through examples.

Although the acquisition of a new knowledge is not enough to produce behavior change in relation to the problem situation, in society in general, it is noticed that, on several occasions, the technical knowledge is lacking. When this knowledge is shared with people in a concrete and well-argued way, it can produce behavioral changes.

In this sense, when analyzing the suggestions and comments of the judges related to the language and writing style of the material, there was inclusion of more qualified information about the biology of the vector and the clarification of conceptual questions since the material, by wanting to teach the subject, sometimes underestimates the reader's ability to understand.

The need for changes in the illustrations and in the coloring of the elaborated material is evident. It was evidenced by the judges who emphasized the importance of these resources to produce an aesthetically well presented, encouraging and convincing material. 
According to the suggested changes, the booklet went through a process of re-elaboration, editing, proofreading, and layout. The topics demarcated by experts related to the adequacy of the visual composition, quality, and attractiveness of the drawings.

The illustrations (drawings, images, photographs, symbols) produced must reach a high level of attention and interest in reading as well as complementing and reinforcing text information. The illustrations need to be accepted by the population at different levels of schooling and generate identification with it ${ }^{(17)}$.

In this way, health professionals must be attentive and critical to the production and validation of this type of resource. Loss of information should be avoided when it presents an inadequate and incompatible format with the population needs. Therefore, health education technologies developed with the perspective of being used in different teaching contexts must be duly tested and validated, so that they can fulfill their educational role ${ }^{(22)}$.

Understanding the procedures of approaches for content and appearance validation is of the utmost importance for researchers and health professionals who are intent on using tools that are increasingly reliable and appropriate for a particular population ${ }^{(9)}$.

However, it is worth mentioning that the information, in the area of public health has certain specificities to be considered. Understanding how this process occurs and how information reaches individuals and communities, how they circulate, how they are interpreted and appropriated, becomes a fundamental aspect in the construction of strategies to prevent and combat diseases, such as dengue and other diseases transmitted by the Aedes aegypti mosquito ${ }^{(19)}$.

\section{Study limitations}

As a methodological limitation of the study, the data was collected from a distance since there was no absolute control of the researcher in meeting deadlines. There was loss of some documents because the collection material was sent by mail for all over Brazil, which entailed extra costs since the documentation had to be sent in a second moment for evaluation. However, this strategy allowed the participation of professionals from different areas of knowledge and in various regions of the country in the construction of educational material, adding content and quality to the booklet.

\section{Contributions to the field of Nursing}

It is important to highlight the importance of this research for the development of new resources and strategies for educational practices, using different settings such as schools and the rural region, making possible the creation of a network of information multipliers, with fewer formalities and more interaction between sender and receiver.

Given this, it is expected that the preparation and validation of this educational booklet, on dengue prevention, may encourage the construction of new didactic tools, especially in the area of nursing. The profession needs to expand and value its productions, even though they are not predominantly composed of artifacts and inventions, but rather of strategies to systematize the work process or the structuring of didactic-pedagogical material for education and health promotion.

\section{CONCLUSION}

After this study, it is considered that the booklet, in general, was considered valid by the expert judges, since it obtained an overall CVI of $70 \%$. However, in the item evaluation, it was found that some did not reach an expected agreement index, impacting on several languages and appearance modifications. Nonetheless, it is believed that the impact of the booklet on the different audiences (adults, adolescents, and children) could not be measured in the present research, since this study did not contemplate the participation of the target audience representatives in the validation process, constituting the objective of a subsequent study.

Thus, in view of the aspects highlighted by the expert judges, from the validation process, the text and the illustrations underwent a re-elaboration, even the items considered valid. Textual suggestions relied on the substitution of expressions, re-elaboration and substitutions of phrases, addition of information, language and grammatical proofreading, factors considered essential in the preparation-production of the educational material.

Thus, in terms of the format and aesthetics of the book, it was imperative the technical evaluation of professionals from other areas that showed, in the material, specific issues of contour, finishing, strokes, balloon shapes, lines, typography, graphic fonts, size scales, color tones, contrast, chromatic settings and printing. The illustrations were all remade, adding clarity, expressiveness, movement, interaction and contextualization.

Therefore, it was concluded that ET, by adapting itself to the suggestions and comments of the judges, can become a valid tool to be used for the population. It aims to inform, in a playful way, the ways of preventing and combating the mosquito transmitting dengue, seeking to promote reflection on the ways of coping with the disease.

\section{REFERENCES}

1. Ministério da Saúde (BR). Portal da saúde. Dengue[Internet]. Brasília. 2015[cited 2017 Jan 24]. Available from: http://portalsaude.saude.gov. br/index.php/o-ministerio/principal/secretarias/svs/dengue

2. Ministério da Saúde (BR). Secretaria de Vigilância em Saúde. Boletim Epidemiológico[Internet]. Brasília 2017 [cited 2017 Jan 21];48(9). Available from: http://portalarquivos.saude.gov.br/images/pdf/2017/marco/31/Monitoramento-dos-casos-de-dengue-febre-dechikungunya-e-febre-pelo-virus-Zika-10-\%202017.pdf

3. Ferreira MVF, Godoy S, Góes FSN, Rossini FP, Andrade D. Lights, camera and action in the implementation of central venous catheter dressing. Rev Latino-Am Enfermagem [Internet]. 2015 [cited 2017 Fev 20];23(6): 1181-6. Available from: Available from: http://www.revistas. 
usp.br/rlae/article/view/108034/106395

4. Moreira AP, Sabóia VM, Camacho ACLF, Daher DV, Teixeira E. Educational game of medication administration: a validation study. Rev Bras Enferm [Internet]. 2014[cited 2017 Jan 20];67(4):528-34. Available from: http://www.scielo.br/pdf/reben/v67n4/0034-7167reben-67-04-0528.pdf

5. Nietsche EA, Lima MGR, Rodrigues MGS, Teixeira JA, Oliveira BNB, Motta CA, et al. Tecnologias inovadoras do cuidado em enfermagem. Rev Enferm UFSM [Internet]. 2012 [cited 2017 Mar 11];2(1):182-9. Available from: https://periodicos.ufsm.br/reufsm/article/view/3591/3144

6. Teixeira E, Mota VMSS. Tecnologias educacionais em foco. São Caetano do Sul: Difusão Editora; 2011.

7. Khurana S, Rao BK, Lewis LES, Bhat R, Purkayastha J, Kamath A, et al. Development and validation of educational leaflet for caregivers of preterm infants. J Clin Diagn Res [Internet]. 2016[cited 2017 Mar 3];10(7):1-4. Available from: https://www.ncbi.nlm.nih.gov/pmc/articles/ PMC5020196/pdf/jcdr-10-YC01.pdf

8. Oliveira PMP, Pagliuca LMF. Avaliação de tecnologia educativa na modalidade literatura de cordel sobre amamentação. Rev Esc Enferm USP [Internet]. 2013[cited 2017 Mar 4];47(1):205-12. Available from: https://periodicos.ufsm.br/reufsm/article/view/3591/3144

9. Medeiros RKS, Ferreira Jr MAF, Pinto PSR, Vitor AF, Santos VEP, Barichello E. Modelo de validação de conteúdo de Pasquali nas pesquisas em Enfermagem. Rev Enf Ref [Internet]. 2015[cited 2017 Mar 24];4(4):127-35. Available from: http://www.scielo.mec.pt/pdf/ref/vserlVn4/ serlVn4a14.pdf

10. Grant JS, Davis LL. Selection and use of content experts for instrument development. Res Nurs Health[Internet].1997[cited 2017 Jan 13];20(3): 269-74. Available from: http://dx.doi.org/10.1002/(SICI)1098-240X(199706)20:3<269::AID-NUR9>3.0.CO;2-G

11. Polit DF, Beck CT. The content validity index: are you sure you know what's being reported? critique and recommendations. Res Nurs Health [Internet]. 2006 [cited 2017 Feb 13];29(5):489-97. Available from: https://www.ncbi.nlm.nih.gov/pubmed/16977646

12. Fernandes CS, Martins MM, Gomes BP, Gomes JA, Gonçalves LHT. Family Nursing Game: desenvolvendo um jogo de tabuleiro sobre família. Esc Anna Nery [Internet]. 2016 [cited 2017 Apr 4];20(1):33-7. Available from: http://www.scielo.br/pdf/ean/v20n1/1414-8145ean-20-01-0033.pdf

13. Sousa CS, Turrini RNT. Validação de constructo de tecnologia educativa para pacientes mediante aplicação da técnica Delphi. Acta Paul Enferm [Internet]. 2012 [cited 2017 May 4];25(6):990-6. Available from: http://www.scielo.br/pdf/ape/v25n6/v25n6a26.pdf

14. Alves GG, Aerts D. As práticas educativas em saúde e a estratégia da saúde da família. Ciência Saúde Coletiva [Internet]. 2011 [cited 2017 May 8];16(1):325. Available from: http://www.scielo.br/pdf/csc/v16n1/v16n1a34.pdf

15. Landeiro MJL, Peres HHC, Martins T. Evaluation of the educational technology "Caring for dependent people" by family caregivers in changes and transfers of patients and tube feeding. Rev Latino-Am Enfermagem [Internet].2016 [cited 2018 Sep 21];24(e):2774. Available from: http://www.scielo.br/pdf/rlae/v24/pt_0104-1169-rlae-24-02774.pdf

16. Albuquerque AFLL, Pinheiro AKB, Linhares FMP, Guedes TG. Technology for self-care for ostomized women's sexual and reproductive health. Rev Bras Enferm [Internet]. 2016[cited 2018 Sep 21];69(6):1164-71. Available from: http://www.scielo.br/pdf/reben/v69n6/en_0034-7167reben-69-06-1164.pdf

17. Teles LMR, Oliveira ASouza, Campos FC, Lima TM, Costa CC, Gomes LFS, et al. Development and validating an educational booklet for childbirth companions. Rev Esc Enferm USP [Internet]. 2014 [cited 2017 Feb 18];48(6):977-84. Available from: http://www.scielo.br/pdf/ reeusp/v48n6/pt_0080-6234-reeusp-48-06-0977.pdf

18. Berardinelli LMM, Guedes NAC, Ramos JP, Silva MGN. Tecnologia educacional como estratégia de empoderamento de pessoas com enfermidades crônicas. Rev Enferm UERJ[Internet]. 2014[cited 2017 Mar 12];22 (5):603-9. Available from: http://www.facenf.uerj.br/v22n5/ v22n5a04.pdf

19. Gonçalves RP, Lima EC, Lima JWO, Silva MGC, Caprara A. Contribuições recentes sobre conhecimentos, atitudes e práticas da população brasileira acerca da dengue. Saúde Soc. São Paulo [Internet]. 2015[cited 2017 Apr 7];24(2):578-93. Available from: http://www.scielo.br/pdf/ sausoc/v24n2/0104-1290-sausoc-24-02-00578.pdf

20. Horey D, Weaver J, Russel H. Information for pregnant women about cesarean birth. Cochrane Database Syst. [s.v.], n.1, 2004.

21. Pommier J, Guevel MR, Jourdan D. Evaluation of health promotion in schools: a realistic evaluation approach using mixed methods. BMC Public. Health [Internet]. 2010[cited 2017 Apr 15];10(1):43. Available from: https://www.ncbi.nlm.nih.gov/pmc/articles/PMC2824736/

22. Maia ER, Lima Jr JF, Pereira JS, Eloi AC, Gomes CC, Nobre MMF. Validação de metodologias ativas de ensino-aprendizagem na promoção da saúde alimentar infantil. Rev Nutr [Internet]. 2012[cited 2017 May 5];25 (1): 79-88. Available from: http://dx.doi.org/10.1590/ S1415-52732012000100008 